Journal of Teacher Education for Sustainability, vol. 16, no. 1, pp. 102-116, 2014

\title{
Educative Experience of the Use of Concept Mapping in Science and Environmental Teacher Training Programmes
}

\author{
Alfonso Pontes-Pedrajas and Marta Varo-Martínez \\ University of Cordoba, Spain
}

\begin{abstract}
Environmental education in the $21^{\text {st }}$ century requires well-instructed teachers with teaching and communication abilities. This paper presents an educational experience developed in several biology and environmental teacher training courses and focused on the treatment of environmental education as a transversal educational topic. For that aim, text analysis techniques, concept mapping and informatics tools have been used to represent individual and collaborative knowledge about environmental topics. 69 students participated in the research. Data about the educational activities developed by the participants have been collected. Furthermore, students have expressed their opinions on the formative process by means of an opinion survey. The outcomes of this study reveal that future teachers and environmental educators consider that concept mapping is a valuable tool to represent their knowledge about environmental education, to encourage reflexive and collaborative learning, to improve teaching communicative abilities and to use effectively ICT in the classroom.
\end{abstract}

Keywords: teacher training, environmental education, concept mapping, collaborative work, CmapTools

\section{Introduction}

The damage to nature caused by human beings has increased noticeably during the last century. Some examples of the environmental degradation are the global climate change, the desertification, the thinning of the ozone layer or the loss of biodiversity. Different countries and international organisations have presented different proposals and initiatives, including environment protection and regeneration programmes or policies to encourage the development of sustainable technologies and the prevention and treatment of contaminants. However, global responses to environmental problems cannot come only from politic interventions and scientific and technologic advances. Concurrently, all inhabitants must get involved (Fien, 1995; Stapp, 1971).

In that sense, since teachers are considered major agents of change (Ilisko, 2007), education has been stated fundamental to promote sustainable development. Indeed, environmental education must be considered the basis for rebuilding the relations between 
people, society and the environment (Hicks \& Holden, 1995; United Nations [UN], 1992). Consequently, it is necessary to incorporate respect for nature in educational programmes so that society becomes aware of the environmental problems and interacts with nature in a sustainable way (Gedžūne \& Gedžūne, 2011; Wellie, 2002).

According to that, countries need qualified educators capable of designing and implementing educational programmes, and planning and organising resources to promote sustainability from an interdisciplinary point of view. In this way, in all the subjects and at all educational levels, environmental topics, such as the respect for nature and sustainability, can be treated by means of different educational activities, such as reading texts, problem solving and concept maps (Espinosa, 2008; Guruceaga \& Gonzalez, 2004). For that purpose and taking into account the importance of emotional and motivational aspects for the teacher professional development (Hargreaves, 1998), it is necessary to reinforce or introduce new specific educative and motivational strategies in teacher training programmes so that teachers of all the educative levels become aware of the importance of environmental education as an instrument to promote respect for nature (Fien, 1995; Gil Pérez, Vilches, Edwards, Praia, Marqués, \& Oliveira, 2003).

In this context, an innovative project called RAEET (Reflexive Approach to Environmental Educators' Training) has been functioning since 2008 in several science and environmental teacher training programmes of the University of Córdoba (Spain) to develop technological, methodological and communicative competences of future teachers (Korthagen, Loughran, \& Russell, 2006) and to promote collaborative, reflexive and meaningful learning with concept maps (Preszler, 2004), related to environmental education topics (Murga-Menoyo, Bautista, \& Novo, 2011).

In this paper, the results of this project are presented. Particularly, the use of concept mapping as a classroom activity in science and environmental teacher training programmes is analysed to check whether it is a useful educational tool to make users reflect on their own knowledge, to identify learning shortcomings and to construct a more meaningful knowledge of nature on which an environmentally responsible behaviour can be based (Andrews, Tressier, \& Mintzes, 2008; Beyerbach, 1988; Buntting, Coll, \& Campbell, 2006).

\section{Concept Mapping and Information Technologies Tools in Teacher Training Programmes}

Concept mapping is a knowledge representation model that promotes the construction of a mental image of the information, making easier the visual identification of the most important concepts, the relationships among them and their hierarchical organisation (Novak \& Gowin, 1984). This graphic representation of concepts provides students and teachers a suitable tool to organise, summarise and communicate their knowledge about any topic, showing information in a schematic and organised way. Consequently, students can use concept mapping as a learning strategy for any subject since it promotes individual or collaborative, reflexive and meaningful learning (Buntting et al., 2006). Additionally, teachers can use concept mapping as teaching resources to show the structure of a topic or to analyse the relationships among the concepts related to the topic (Novak \& Cañas, 2006). In that way, concept mapping may complement teachers' explanations and improve students' comprehension about it. 
The educative use of concept mapping is essentially based on the meaningful learning theory (Ausubel, 2000; Ausubel, Novak, \& Hainesian, 1978) and constructivist learning philosophy (Anderson \& Demetrius, 1993; Novak \& Cañas, 2006). It is also based on the study of the relationships among science, technology, society and environment STSE relations (González, 2008). According to constructivism, students' new knowledge is based on prior knowledge, since the latest can be considered as a cognitive scheme that may be enriched and restructured while new knowledge is gradually acquired and integrated in the memory (Novak \& Cañas, 2004). Thus, concept maps not only are very useful to represent students' knowledge and its evolution during the formative process, but also to identify their learning difficulties (Jones, Carter, \& Rua, 2000). Furthermore, concept mapping motivates students (Schaal, 2010) as it is suitable for developing reflexive and collaborative learning (Edwards \& Fraser, 1983) and can be used both as teaching or assessing tools (Buehl \& Fives, 2011). For all these reasons, concept mapping is a valuable teaching methodology that provides a measure of conceptual understanding (Andrews et al., 2008; Buehl \& Fives, 2011; Miller et al., 2009; Miranda-Correia, Silva, \& Romano-Junior, 2010; Moreira, 1985; Novak \& Gowin, 1984; Proctor \& Bernstein, 2013; Stuart, 1985).

Indeed, concept mapping has been used for decades in scientific education (Stewart, 1980; Stuart, 1985) and in teachers' and environmental educators' education and training programmes (Andrews et al., 2008; Guruceaga \& González, 2004; Novak, 1978). Specifically, in the field of environmental education, Balgopal and Wallace (2009) used concept maps to identify students' misconceptions and explore changes in knowledge about ecological concepts when applying an educational methodology, focused not only on concepts, but also on the connections between cognitive and affective domains. Additionally, a methodology based on the use of concept mapping and a Likert-scale inventory was developed to work on topics related to conservation and preservation of animal species, finding out that students with a greater knowledge of animal species are more aware of its conservation and protection (Barney, Mintzes, \& Yen, 2005). Finally, Vanhear and Pace (2008) describes a new teaching methodology based on the use of concept maps, together with Vee Heuristics, to promote, among 6 and 7 years old children, meaningful learning about nature and, in the long run, the environmentally responsible behaviour based on this knowledge.

As far as teacher training is concerned, Mosothwane (2002) proved that teachers with a solid understanding of the main concepts of their areas are more effective teachers. Accordingly, concept mapping is a quite helpful strategy in teacher training programmes since, as mentioned before, it promotes reflexive and meaningful learning (Beyerbach, 1988). In this line of work, Zak and Munson (2008) investigated pre-service teachers' conceptual understanding of basic ecological concepts using concept maps. Also, metaconceptual teaching activities, such as concept mapping, have been proved to help preservice teachers to change alternative misconceptions related to flowering plants (Nejla, Meryem, \& Mehmet, 2011). Finally, in the last decades, the use of concept maps for teacher training has experienced a considerable increase due to specific software based on information and communication technologies (ICT). According to MacKinnon and Aylward (2009), ICT provide promising chances to create new teaching and learning frameworks that enrich the educational context in which students and teachers are enrolled. They show the advantages of using of ICT in teacher training programmes, describing experiences in which electronic portfolios, collaborative concept mapping 
and educational digital forums are used (Tergan, 2005). In addition, ICT can be used to improve information search processes, develop new communicative technologies, design any kind of didactic resources, implement simulation and modelling tools or develop collaborative and intuitive learning environments (Ojeda, Gutiérrez, \& Perales, 2009).

Specifically, ICT have an important role in the field of environmental education, since they can open access to information and knowledge about sustainability and, consequently, promote public awareness of the need for sustainable development (Ospina, 2012). In that line, for instance, considering that promoting active citizens learning must be based on the principles of the ExConTra learning paradigm (experiencing, constructing, transforming), a web-based learning environment, including several ICT tools (concept maps, spreadsheets, presentations, paint tools, word processing and Venn diagrams), has been developed to introduce primary school learners to the issue of climate change from a cross-thematic and interdisciplinary curricular approach (Makrakis, Gkotzos, \& Larios, 2012).

Combining both tools (concept mapping and ICT), CmapTools is open software developed by the Florida Institute for Human \& Machine Cognition (IHMC) that can be used to design and use these maps in the educative processes (Cañas, 2004; Cañas, Hill, \& Lott, 2003; Daley, Cañas, \& Stark, 2007; Martínez, Perez, Suero, \& Pardo, 2013). This software lets the user build, save and modify concept maps easily and attach to them any kind of digital resource (Novak \& Cañas, 2006). In that way, the design of concept maps with informatics tools and, particularly, with CmapTools, helps future teachers to use ICT in the classroom effectively, improves teaching communicative abilities, encourages educational innovation and increases future educators' motivation (Pontes, 2012). For all these reasons, numerous educational activities based on the design of concept maps with CmapTools have been developed in environmental education (Echarri \& Puig, 2009; Guruceaga \& González, 2004; Vanhear \& Pace, 2008). Thus, it can be interesting for future educators to learn concept mapping techniques and informatics tools for its design, such as CmapTools (González, 2008).

\section{RAEET Project: Educational Proposal and Design of the Research}

As mentioned before, different studies have proved the potential of ICT as educational tools (Ojeda et al., 2009) and the use of concept maps as individual and collaborative learning strategies to motivate students (Schaal, 2010). Thus, the software CmapTools, which combines both elements, can improve the motivation of environmental educators (Murga-Menoyo et al., 2011). In this context, the RAEET project has been carried out to develop a new methodology proposal for environmental teacher training programmes.

The aims of this study are:

- to develop a methodology proposal for the treatment of environmental education, as a transversal and interdisciplinary topic, based on the analysis of texts and concept mapping to promote reflexive and collaborative learning;

- to use informatics resources, such as CmapTools, for the elaboration of concept maps related to environmental education and for the acquisition of communicative abilities, promoting the effective use of ICT in teacher training programmes;

- to design a survey to analyse future teachers' motivations and opinions on the activities, resources and methodology used in this formative proposal. 


\section{Educational Proposal and Data Collection}

The data analysed in this paper have been collected in the study course entitled "Knowledge Representation by Concept Mapping” of the master's degree study programmes "Environmental Education" and "Biology Teachers' Training" at the University of Cordoba in Spain. In this study course, the didactic treatment of transversal topics related to environmental education (climate change, renewable energies, sustainable development, environmental education and so on) is tackled by the analysis of text about these topics and concept mapping as educational activities to promote the reflexive and collaborative approach in teacher training programmes. Furthermore, by knowledge representation, it is expected that future teachers acquire general teaching skills, such as the effective use of ICT and communicative abilities in the classroom (Pontes, 2012).

Firstly, in order to get used to this knowledge representation technique (Novak \& Cañas, 2006), students make, with pen and paper, individual concept maps based on the comprehensive reading of a document related to environmental education. After that, in order to encourage team work abilities, students are put into two or three people groups to discuss their individual concept maps and re-elaborate a collaborative one (Pontes \& Varo, 2013). Secondly, students learn to use CmapTools and construct with it individual and collaborative digital concept maps related to environmental education. These collaborative concept maps could be done either in the classroom or online thanks to the collaborative work tool that the software provides (Novak \& Cañas, 2006; Daley, et al., 2007). Additionally, students elaborate multimedia presentations with their concept maps and they present them in the classroom to promote the debate and the acquisition of teaching communicative abilities.

The final mark of the study course is based on the average marks of the individual and collaborative concept maps elaborated with CmapTools. To assess these concept maps, according to previous studies (Murga-Menoyo et al., 2011; Proctor \& Bernstein, 2013; Stuart, 1985), an evaluation pattern has been designed by the teachers taking part in the innovative experience (Table 1).

Table 1

Qualitative Evaluation Pattern for the Concept Maps

\begin{tabular}{clc}
\hline Quality & \multicolumn{1}{c}{ Evaluation Criteria } & Mark \\
\hline (I) Low & $\begin{array}{l}\text { The concept map shows incorrect concepts or a lack of important } \\
\text { concepts and has technical (hierarchy, visual impact) or semantic (link } \\
\text { sentences) faults }\end{array}$ & $0-4,9$ \\
\hline (II) Suitable & $\begin{array}{l}\text { The concept map includes most of the main concepts and semantic } \\
\text { relationships but has technical (hierarchy, visual impact) or semantic } \\
\text { (link sentences, nodes with different concepts) faults. }\end{array}$ & $5-7,5$ \\
\hline (III) High & $\begin{array}{l}\text { The concept map includes the main concepts of the topic and the link } \\
\text { sentences are correct. The hierarchy is appropriate and it has a good } \\
\text { visual impact. }\end{array}$ & $7,6-10$ \\
\hline
\end{tabular}

At the end of the workshop, students filled out an open questionnaire to collect their opinions on the development of the educational experience (Appendix 1). This survey is an important element to promote reflexive learning (Pontes, 2012) and sheds light on the research topic. Since the survey is composed of open questions, a qualitative analysis of the answers has been done. Specifically, the most frequent answers have 
been classified into different categories and counted by means of their relative frequency. Moreover, the most representative opinions have been identified, and interesting conclusions have been drawn.

Thus, there are two types of data collected: individual/collaborative concept maps based on comprehensive reading of texts related to environmental topics and opinion surveys filled out by the research participants. The first set of data provides the participants' knowledge and the influence of collaborative work on it. From the surveys, it is possible to highlight the participants' opinions on the elaboration of individual concept maps, the influence of collaborative work, the use of CmapTools, the possible application of concept mapping in environmental education and the educational value of the innovative experience developed.

\section{Participants}

Since 2009, 69 people have participated in this educational innovation project developed in the study course entitled "Knowledge Representation by Concept Mapping" of the master's degree study programmes "Environmental Education" (25 participants) and "Biology Teachers' Training" (44 participants). The mean age of the group was 26.3 years, and the majority of the participants were biology, environmental sciences or veterinary sciences graduates. Most of the participants had some skill in word processing software and had knowledge of educational online platforms. Only 3 participants (4.4 $\%$ ) knew how to use software for the elaboration of concept maps.

\section{Results}

\section{Individual and Collaborative Knowledge Representations}

The analysis of the individual (Pontes, 2012) and collaborative (Pontes \& Varo, 2013) concept maps elaborated by the participants show a positive influence of the team work on the concept map design. Table 2 shows the results of the T-Student analysis obtained when comparing the average of the marks given by the teachers to the individual (ICM) and collaborative (CCM) concept maps, according to the assessment criteria described in Table 1. Additionally, other important didactic aspects of this activity include the social interactions developed in the classroom and the increased students' motivation and interest in participating actively when working in groups (Preszler, 2004; Schaal, 2010). Thus, the elaboration of collaborative concept maps with computer resources promotes general competence in communication, which is very important in current educational settings (Chiu, Huang, \& Chang, 2000; MacKinnon \& Aylward, 2009).

Table 2

Comparative Analysis of the Average Marks of the Individual (ICM) and Collaborative (CCM) Concept Maps

\begin{tabular}{lccc}
\hline Master & ICM & CCM & T-Student $(\mathrm{p})$ \\
\hline Master of Environmental Education $(\mathrm{n}=25)$ & 5.84 & 7.73 & $13,952(\mathrm{p}<0,01)$ \\
\hline Master of Biology Teacher Training $(\mathrm{n}=44)$ & 5.67 & 7.59 & $14,173(\mathrm{p}<0,01)$ \\
\hline Total $(\mathrm{n}=69)$ & 5.73 & 7.64 & $14,105(\mathrm{p}<0,01)$ \\
\hline
\end{tabular}


Finally, in order to promote the use of concept mapping as a technique to represent the knowledge acquired in teacher training programmes, future educators are encouraged to use concept maps in their final project to obtain a master's degree. As an example of this interesting activity, Figure 1 shows the concept map used by one of the students to schematise an educational unit related to the water cycle. This example shows that future teachers use properly concept mapping to represent complex knowledge of scientific and educational topics. Furthermore, according to the instructors, students using concept mapping display good communicative abilities, which are important for their future profession.

\section{Opinions and Motivations of the Use of Concept Mapping in Environmental Teacher Training}

The use of individual concept maps in teacher training programmes. The first question of the survey was as follows: How do you evaluate the use of concept maps as a tool to represent the knowledge in teachers' initial formation? The learners were also asked to discuss the advantages and disadvantages of elaborating individual maps.

The answers to the first question have been classified into the categories.

(A) Evaluation of the elaboration of individual concept maps as a technique to represent the ideas extracted from a text related to environmental education:

A1. Good $(61.0 \%)$

A2. Suitable $(18.8 \%)$

A3. $\operatorname{Bad}(10.1 \%)$

A4. No answer $(10.1 \%)$

(B) Reasons for the evaluation:

B1. They indicated some advantages or educational interest points $(68.2 \%)$

B2. They indicated some disadvantages $(13.0 \%)$

B3. They indicated neither advantages nor disadvantages $(18.8 \%)$

Accordingly, bringing together the results of A1 and A2, about $80 \%$ of the participants favourably evaluated the use of concept mapping as a strategy to individually represent the knowledge acquired from a text related to environmental education. Importantly, $72 \%$ of the students stated that they were motivated while learning the technique and found the activity quite interesting. Furthermore, most of the participants considered that, although concept mapping requires reflection and an intellectual effort, it helped them to better understand the topic they were representing. Some of them also thought that the design of concept maps promotes self-learning. Several individuals pointed out that patience and repeated practice are necessary to reach a good result. Few students had experienced doubts or confusion while learning this technique, stating that concept selection represented a greater difficulty. Finally, some students declared that the design of the first individual map was not easy, and different drafts had to be elaborated before producing the final satisfactory map.

Use of CmapTools for concept mapping. The second question of the survey was as follows: What do you think about the use of CmapTools for concept map elaboration? The learners were also asked to discuss the advantages and disadvantages of this tool.

The answers to the second question have been classified into the categories. 
(A) Evaluation of CmapTools as a tool to design digital concept maps:

A1. Good $(76.8 \%)$

A2. Suitable $(14.5 \%)$

A3. $\operatorname{Bad}(2.9 \%)$

A4. No answer $(5.8 \%)$

(B) Reasons for the evaluation:

B1. They indicated some advantages $(66.7 \%)$

B2. They indicated some disadvantages $(11.6 \%)$

B3. They indicated neither advantages nor disadvantages are indicated $(21.7 \%)$

Thus, about $90 \%$ of the participants gave a favourable evaluation of CmapTools to elaborate digital concept maps. Among the reasons for this evaluation, the students pointed out that, despite the doubts, CmapTools is easy to learn. In addition, they considered that this software is very suitable for teacher training programmes. Among the advantages, they underlined that, with CmapTools, concept maps can be saved in order to be extended or reorganised later, the software lets the user attach digital resources, such as documents, figures or even videos. It was also pointed out that, thanks to the colours and geometrical shapes included in the software, the maps created with it encourage communication in the classroom. Most of them $(68 \%)$ conclude that "learning CmapTools to design concept maps is fun and motivating”.

Elaboration of collaborative concept maps. The following questions of the survey were related to the elaboration of collaborative concept maps: How do you evaluate the elaboration of concept maps in groups? Do you think this activity encourages the learning process?

The answers to the third question have been classified into the categories.

(A) Evaluation of collaborative concept maps:

A1. Good $(65.2 \%)$

A2. Suitable $(20.3 \%)$

A3. $\operatorname{Bad}(5.8 \%)$

A4. No answer $(8.7 \%)$

(B) Influence of the collaborative concept mapping in teacher training:

B1. Positive and they give reasons in favour $(40.6 \%)$

B2. Positive but they do not give reasons in favour $(34.8 \%)$

B3. Not important $(10.1 \%)$

B4. Answer not justified (14.5\%)

Combining the results of the categories A1 and A2, it is possible to state that $85 \%$ of the participants evaluated favourably the elaboration of collaborative concept maps to promote the exchange of ideas in a collaborative team atmosphere. Specifically, they state that, "It is an interesting and fan activity". Many of the participants considered that, thanks to interaction in the group, the topic is better understood and that individual concept maps can be improved, although sometimes it is difficult to agree on the concept selection and hierarchy. A lot of students also stated that these activities encourage social interaction.

Global evaluation of the educational experience and the possible applications of concept mapping in environmental education. Finally, the learners were asked to express their opinion on the experience and point out the roles that concept mapping can have in environmental education and teacher training. 
The answers to the last question have been classified into the categories.

(A) Global evaluation of the educational experience:

A1. Positive and they provide the reasons in favour $(36.2 \%)$

A2. Positive, but they do not provide the reasons in favour $(31.9 \%)$

A3. Negative and they provide the reasons against $(5.8 \%)$

A4. Negative, but they do not provide the reasons against $(7.2 \%)$

A5. No answer $(18.9 \%)$

(B) Educational applications of concept mapping in environmental education:

B1. Point out more than three applications $(53.6 \%)$

B2. Point out less than three applications $(26.1 \%)$

B3. No application/no answer $(20.3 \%)$

Accordingly, $68 \%$ of the participants positively evaluated the educational activities proposed, including the activities developed and the resources used, considering it a motivating, fun and interesting activity. Many of them considered the experience interesting and innovative, and they agree that the treatment of topics related to environmental education by means of the analysis of texts and the elaboration of individual and collaborative concept maps is very motivating.

Additionally, most of the future educators thought that CmapTools had contributed to the development of teaching competences (in a technological, methodological and communicative sense) that would be suitable in their future professional career as biology teachers or environmental educators.

In general, more than $50 \%$ of the students thought that concept mapping could be very useful in environmental education because it helps teachers to organise the contents of the subject. Moreover, students can use them as a study technique to organise their thoughts. Some of them also pointed out that knowledge representation activities promote autonomous learning and encourages reflection on their own knowledge.

\section{Discussion and Conclusions}

In this paper, an experience developed since 2009 within the framework of an innovative educational project at the University of Cordoba is described. The project seeks to promote a reflexive and collaborative educational strategy in the master's degree programmes: "Biology Teachers' Training" and "Environmental Education". To do this, different kinds of teaching activities are implemented: the analysis of texts related to environmental education, the elaboration of individual and collaborative concept maps and the use of CmapTools to elaborate digital maps and design multimedia expositions with concept maps (Andrews et al., 2008; Balgopal \& Wallace, 2009; Guruceaga \& González, 2004; Zak \& Munson, 2008).

Thus, one of the aims of this experience was to teach future environmental educators how to use concept mapping as an individual learning strategy that promotes the formation of more expressive teachers since it facilitates their reflection on their own knowledge (Nejla et al., 2011; Reitano \& Green, 2012). Additionally, the proposed methodology promotes teamwork (Preszler, 2004), and it is a useful way of applying ICT tools effectively in environmental education (Ojeda et al., 2009) and in teacher training programmes in general (Makrakis et al., 2012). Furthermore, the proposed methodology fosters communication in the classroom, the acquisition of teaching competences and future educators' motivation towards their self-development and professional progress 
(Hargreaves, 1998; Korthagen et al., 2006; MacKinnon \& Aylward, 2009; MurgaMenoyo et al., 2011; Preszler, 2004; Schaal, 2010).

In this experience, the learning outcomes have been analysed by evaluating the proposed activities and the concept maps created by the students. In addition, by means of a survey, the students' opinions on the experience have been gathered to improve the design of the experience (Buntting et al., 2006; Murga-Menoyo et al., 2011).

It is possible to conclude that future teachers have learned to design concept maps, and they think that concept maps are useful tools to graphically represent the contents of an environmental education topic and to present these contents in any kind of academic exposition. In addition, it is possible to state that future teachers learn very quickly how to use CmapTools in order to construct concept maps, how to attach digital educational resources and how to use these concept maps to improve classroom communication. Furthermore, it has been observed that the elaboration of collaborative concept maps in the classroom or online, thanks to the synchronous collaboration feature of CmapTools (Novak \& Cañas, 2006), promotes social interaction among students and the development of the ability to work in groups, confirming the results of previous studies in the field of teacher training (Preszler, 2004; Schaal, 2010). In that sense, the opinions on the participants are quite positive, and they highlight that this tool promotes methodological change and, mainly, the motivation of the users (Chiu et al., 2000; MacKinnon \& Aylward, 2009).

It is important to point out that this paper focuses on describing the educational experience based on concept mapping and the analysis of the future teachers' opinions on the methodology and educational activities proposed. However, the project's aims are wider, and the use of concept mapping is being promoted as a technique to represent the knowledge in teacher training programmes. Thus, future teachers are encouraged to use concept maps to sum up an educational unit (Figure 1). The analysis of the experience points out that students that use concept mapping develop communicative abilities.

It is also possible to conclude that the results obtained in this study, related to the students' opinions on the use of concept mapping in teacher training programmes, confirm previous research outcomes (MacKinnon \& Aylward, 2009; Murga-Menoyo et al., 2011). However, it is important to point out that this experience is the first phase of a wider innovative project. In the future stages, a new opinion survey, based on a Likert scale, will be carried out. Additionally, since environmental education is a transversal topic that may be tackled in all areas of the educational system (Espinosa, 2008), the use of concept mapping and the analysis of texts related to environmental challenges, such as pollution or climate change, will be proposed in other teacher training programmes in order to promote favourable behaviours towards sustainable development among future teachers (Gil Pérez et al., 2003; Fien, 1995). Thus, by means of this project, a transversal and interdisciplinary treatment of environmental education will be promoted in different teacher training programmes. In that way, due to the great influence of teachers and teaching as agents of change in society, this educational experience developed in teacher training programmes is expected to contribute to the attainment of the environmental education objectives and to promote the sustainable development (Fien, 1995; Ilisko, 2007; Gedžūne \& Gedžūne, 2011). 


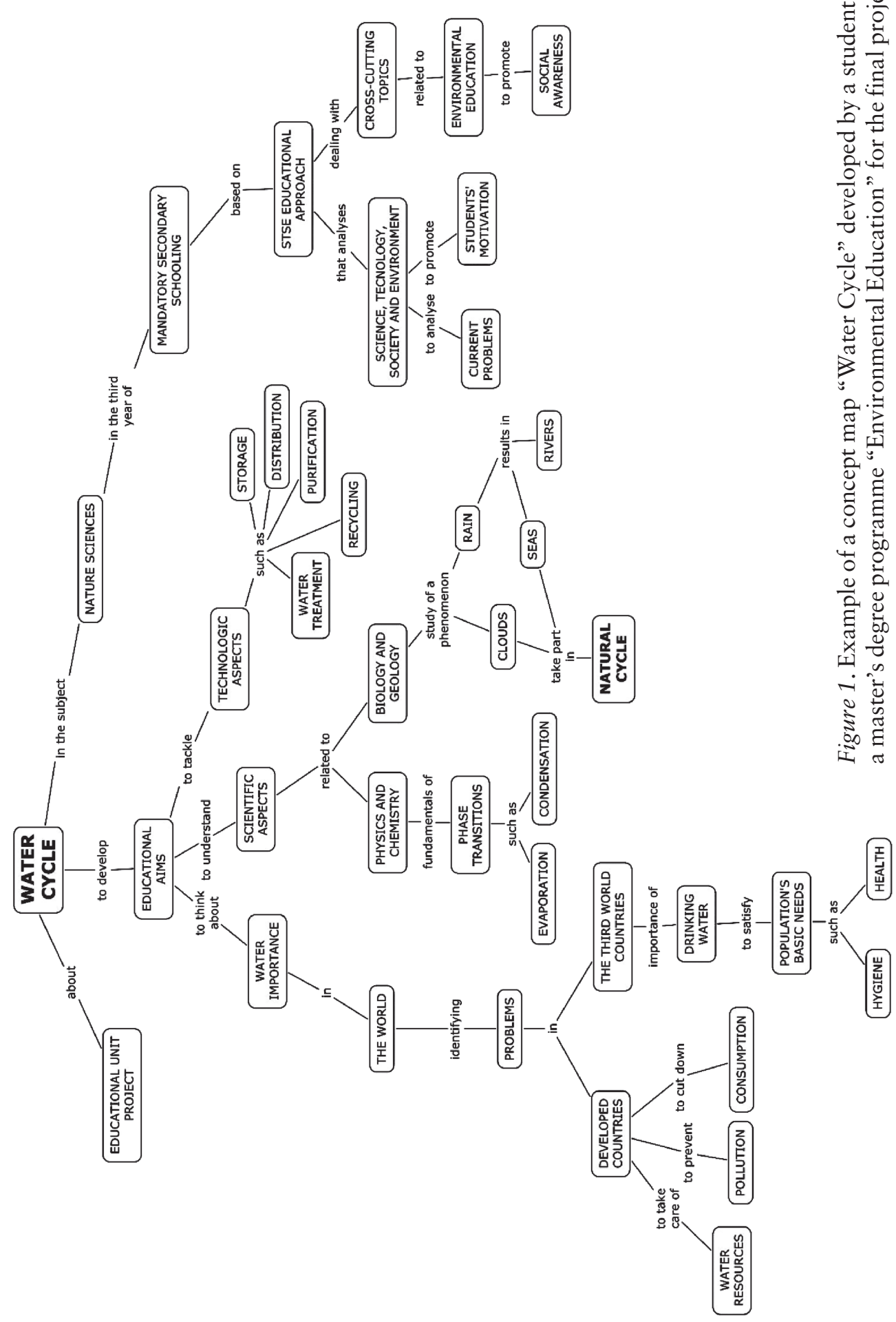

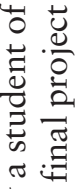

준

은

8 苛

늘

元

킁

这

薄

छ

०5

는

矛过

$\therefore$

芯

更 


\section{References}

Anderson, O. R., \& Demetrius, O. J. (1993). A flow-map method of representing cognitive structure based on respondent's narrative using science content. Journal of Research in Science Teaching, 30(8), 953-969.

Andrews, K. E., Tressier, K. D., \& Mintzes, J. J. (2008). Environmental understanding: An application of concept mapping strategy. Environmental Education Research, 14(5), 519-536.

Ausubel, D. P. (2000). The acquisition and retention of knowledge: A cognitive view. Dordrecht: Kluwer Academic.

Ausubel, D., Novak, J. D., \& Hainesian, H. (1978). Educational psychology. A cognitive view. New York: Holt, Rinehan and Winston.

Balgopal, M. M., \& Wallace, A. M. (2009). Decisions and dilemmas: Using writing to learn activities to increase ecological literacy. Journal of Environmental Education, 40(3), 13-26.

Barney, E. C., Mintzes, J. J., \& Yen, C. F. (2005) Assessing knowledge, attitudes and behavior toward charismatic megafauna: The case of dolphins. Journal of Environmental Education, 36(2), 41-55.

Beyerbach, B. A. (1988). Developing a technical vocabulary on teacher planning: Preservice teachers' concept maps. Teaching and Teacher Education, 4, 339-347.

Buehl, M., \& Fives, H. (2011). Best practices in educational psychology: Using evolving concept maps as instructional and assessment tools. Teaching Educational Psycho$\log y, 7(1), 62-87$.

Buntting, C., Coll, R., \& Campbell, A. (2006). Students views of concept mapping use in introductory tertiary biology classes. International Journal of Science and Mathematics Education, 4(4), 641-668.

Cañas, A. J. (2004). CmapTools: A knowledge modeling and sharing environment. In A. J. Cañas, J. D. Novak \& F. M. González (Eds.), Concept Maps: Theory, Methodology, Technology. Proceedings of the First International Conference on Concept Mapping (pp. 125-133). Pamplona: Universidad de Navarra.

Cañas, A. J., Hill, G., \& Lott, J. (2003). Support for constructing knowledge models in CmapTools. Retrieved May 1, 2014, from http://www.ihmc.us/Publications/

Chiu, C. H., Huang, C., \& Chang, W. (2000).The evaluation and influence of interaction in network supported collaborative concept mapping. Computers \& Education, 34(1), 17-25.

Daley, B. J., Cañas, A. J., \& Stark, T. (2007). CmapTools: Integrating teaching, learning and evaluation in online courses. New Directions for Adult and Continuing Education, 113, 37-47.

Echarri, F., \& Puig, J. (2009). Aprendizaje significativo y Educación Ambiental mediante el programa de software libre CmapTools [Meaningful learning and environmental education with free software CmapTools]. Comunicación y pedagogía: Nuevas tecnologías y recursos didácticos [Communication and Pedagogy: New Technologies and Didactic Resources], 235, 16-20.

Edwards, J., \& Fraser, K. (1983). Concept maps as reflections of conceptual understanding. Research in Science Education, 13, 19-26.

Espinosa, J. M. (2008). La educación ambiental: un modelo de trabajo transversal [Environmental education: A cross-cutting model]. Caleidoscopio: Revista digital 
de contenidos educativos [Kaleidoscope: Digital Journal of Educational Resources], $1,84-86$.

Fien, J. (1995). Teacher for sustainable world: The environmental and development education project for teacher education. Environmental Education Research, 1(1), 21-33

Gedžūne, I., \& Gedžūne, G. (2011). Exploring and promoting ecological consciousness in teacher education: The possibilities of educational action research in education for sustainable development. Journal of Teacher Education for Sustainability, 13(1), 43-61.

Gil Pérez, D., Vilches, A., Edwards, M., Praia, J., Marqués, L., \& Oliveira, T. (2003). A proposal to enrich teachers' perception of the state of the world: First results. Environmental Education Research, 9(1), 67-90.

González, F. (2008). El Mapa conceptual y el Diagrama V. Recursos para la Enseñanza Superior en el siglo XXI [Concept maps and V diagram. Resources for higher education in the $21^{\text {st }}$ century]. Madrid: Narcea.

Guruceaga, A., \& González, F. (2004). Aprendizaje significativo y educación ambiental: análisis de los resultados de una práctica fundamentada teóricamente [Meaningful learning and environmental education: Analysis of the results of a theoretical supported practice]. Enseñanza de las Ciencias [Science Education], 22(1), 115-136.

Hargreaves, A. (1998). The emotional practice of teaching. Teaching and Teacher Education, 4(8), 835-854.

Hicks, D., \& Holden, C. (1995). Exploring the future: A missing dimension in environmental education. Environmental Education Research, 1(2), 185-193.

Ilisko, D. (2007). Teachers as agents of societal change. Journal of Teacher Education for Sustainability, 7, 14-26.

Jones, M. G., Carter G., \& Rua, M. J. (2000). Exploring the development of conceptual ecologies: Communities of concepts related to convention and heat. Journal of Research in Science Teaching, 37, 139-159.

Korthagen, F., Loughran, J., \& Russell, T. (2006). Developing fundamental principles for teacher education programs and practices. Teaching and Teacher Education, 22(8), 1.020-1.041.

MacKinnon, G. R., \& Aylward, M. L. (2009). Models for building knowledge in a technology-rich setting: Teacher education. Canadian Journal of Learning and Technology, 35(1), 1-7.

Makrakis, V., Gkotzos, D., \& Larios, N. (2012). ICT-enabled climate change education and children's rights. Journal of Teacher Education for Sustainability, 14(2), 89-110.

Martínez, G., Perez, A. L., Suero, M. I., \& Pardo, P. J. (2013).The effectiveness of concept maps in teaching physics concepts applied to engineering education: Experimental comparison of the amount of learning achieved with and without concept maps. Journal of Science Education and Technology, 22(2), 204-214.

Miller, K. J., Koury, K. A., Fitzgerald, G. E., Hollingsead, C., Mitchem, K. J., Tsai, H. H., \& Park, M. K. (2009).Concept mapping as a research tool to evaluate conceptual change related to instructional methods. Teacher Education and Special Education, 32(4), 365-378.

Miranda-Correia P. R., Silva, A. C., \& Romano-Junior, J. G. (2010). Concept maps as a tool for evaluation in classroom. Revista Brasileira de Ensino de Física [Brazilian Journal of Physics Education], 32(4), 4402(1)-4402(8). 
Moreira, M. A. (1985). Concept mapping: An alternative strategy for evaluation. Assessment and Evaluation in Higher Education, 10(2), 159-168.

Mosothwane, M. (2002). Pre-service teachers' conceptions of environmental education. Research in Education, 68, 26-40.

Murga-Menoyo, M. A., Bautista, M. J., \& Novo, M. (2011). Mapas conceptuales con CmapTools en la enseñanza universitaria de la educación ambiental. Estudio de caso en la UNED [Concept maps with CmapTools in environmental education in higher education. UNED case study]. Enseñanza de las Ciencias [Science Education], 29(1), 47-60.

Nejla, Y., Meryem, S., \& Mehmet, Y. (2011). The effect of metaconceptual teaching activities on pre-service biology teachers' conceptual understanding about seed plants. Educational Sciences: Theory and Practice, 11(1), 459-464.

Novak, J. D. (1978). A theory of education as a basis for environmental education. In T. S. Bakshi \& Z. Naveh (Eds.), Environmental education. Principles, methods and applications (pp. 129-138). Nueva York: Plenum Press.

Novak, J. D., \& Cañas, A. J. (2004). Building on constructivist ideas and CmapTools to create a new model for education. In A. J. Cañas, J. D. Novak \& F. M. Gonzalez (Eds.), Concept Maps: Theory, Methodology, Technology. Proceedings of the First International Conference on Concept Mapping (pp. 1-9). Pamplona: Universidad de Navarra.

Novak, J. D., \& Cañas, A. J. (2006).The theory underlying concept maps and how to construct them. Retrieved May 1, 2014, from http://www.ihmc.us/Publications/

Novak, J. D., \& Gowin, D. B. (1984). Learning how to learn. New York: Cambridge University Press.

Ojeda, F., Gutiérrez, J., \& Perales, F. J. (2009). Qué herramientas proporcionan las Tecnologías de la Información y la Comunicación a la educación ambiental? [What tools do information and communication technologies provide for environmental education?] Revista Eureka sobre Enseñanza y Divulgación de las Ciencias [Eureka Journal on Science Education and Spreading], 6(3), 318-344.

Ospina, A. V. (2012). The outcome of Rio+20: An ICT perspective on the "Future we want”. Retrieved August 23, 2013, from http://niccd.wordpress.com/

Pontes, A. (2012). Representación y comunicación del conocimiento con mapas conceptuales en la formación del profesorado de ciencia y tecnología [Knowledge representation and communication with concept maps in science and technology teacher training]. Revista Eureka sobre Enseñanza y Divulgación de las Ciencias Eureka [Journal on Science Education and Spreading], 9(1), 108-125.

Pontes, A., \& Varo, M. (2013). Aprendizaje colaborativo con mapas conceptuales en la formación inicial del profesorado de secundaria [Collaborative learning with concept maps in secondary teachers' training]. In Actas IX Congreso Internacional de Enseñanza de las Ciencias [Proceedings of the $9^{\text {th }}$ International Congress on Science Education] (pp. 2826-283). Girona: Universidad de Girona.

Preszler, R. W. (2004). Cooperative concept mapping improves performance in biology. Journal of College Science Teaching, 33, 30-35.

Proctor, J. D., \& Bernstein, J. (2013). Environmental connections and concept mapping: Implementing a new learning technology at Lewis \& Clark College. Journal of Environmental Studies and Sciences, 38(1), 30-41. 
Reitano, P., \& Green, N. C. (2012).The value of concept mapping in developing professional growth in a geography methods course. International Journal of Multiple Research Approaches, 6(2), 160-174.

Schaal, S. (2010). Cognitive and motivational effects of digital concept maps in preservice science teacher training. Procedia Social and Behavioral Sciences, 2, 640647.

Stapp, W. B. (1971). An environmental education program (K-12) based on environmental encounters. Environment and Behavior, 3(3), 263-283.

Stewart, J. (1980). Techniques for assessing and representing information in cognitive structure. Science Education, 64(2), 223-235.

Stuart, H. A. (1985). Should concept map be scored numerically? European Journal of Science Education, 7(1), 73-81.

Tergan, S. O. (2005). Digital concept maps for managing knowledge and information. In Knowledge and information visualization (pp. 185-204). Heidelberg: Springer.

UN (United Nations). (1992). The United Nations conference on environment and development: Agenda 21 Rio Declaration. Paris: UNESCO.

Vanhear, J., \& Pace, P. J. (2008). Integrating knowledge, feelings and action: Using Vee heuristics and concept mapping in education for sustainable development. Journal of Teacher Education for Sustainability, 10, 42-55.

Wellie, D. (2002). Making biodiversity meaningful through environmental education. International Journal of Science Education, 24, 1143-1156.

Zak, K. M., \& Munson, B. H. (2008). An exploratory study of elementary preservice teachers' understanding of ecology using concept maps. Journal of Environmental Education 39(3), 32-46.

Correspondence concerning this paper should be addressed to Marta Varo-Martínez, PhD, Department of Applied Physics, Albert Einstein Building, University of Cordoba, 14071 Córdoba, Spain. Email: fa2vamam@uco.es 